\title{
Pogovorni in narečni izrazi v slovenskih dramskih prevodih - soočanje s prevajalskimi zagatami
}

\section{Tomaž Onič}

\begin{abstract}
IZVLEČEK: V članku so povzeti izsledki analize prevoda drame Hišnik Harolda Pinterja v slovenščino. Pri tem avtor poskuša opredeliti in raziskati kritična mesta v besedilu, kjer je prevajalec pri prevajanju pogovornih izrazov naletel na objektivne težave, izpostavlja pa tudi tiste pomanjkljivosti prevoda, ki bi se jim bilo z uporabo vnaprej premišljene in natančno izdelane prevajalske strategije mogoče izogniti.
\end{abstract}

ABSTRACT: This article summarizes the findings of an analysis of a Slovenian translation of Harold Pinter's play The Caretaker (Sln. Hišnik). The author defines and investigates the critical places in the text where the translator encountered difficulty in translating colloquial expressions, and also points out shortcomings in the translation that could have been avoided by using a well-thought-out and precise translation strategy.

\section{Uvod}

Kadar govorec $\mathrm{v}$ vsakdanjem živem jeziku uporabi narečno ali pogovorno besedo ali kateri drugi element jezika, ki ne spada v trenutno vzpostavljeno jezikovno zvrst, bo sprejemnik z določenimi jezikovnimi izkušnjami in splošno razgledanostjo to verjetno zaznal. Posameznikova sposobnost uvrščanja besed v ustrezen segment jezika je sicer lahko rezultat posedovanja teoretičnega znanja, vendar gre najpogosteje za intuitivno predstavo o tem, ali nek jezikovni element, najpogosteje je to beseda ali besedna zveza, v dani kontekst spada ali ne. V primeru, ko sprejemnik zazna tovrsten »preboj« zvrsti, je učinek lahko pozitiven, a le tedaj, ko je načrtovan, sicer deluje moteče in izkrivlja želeno percepcijo. Tudi dramska besedila so del živega jezika; morda še celo nekoliko bolj od ostalih književnih vrst, saj se skozi svojo odrsko manifestacijo skoraj popolnoma zlijejo z naravno rabo govorjenega jezika. Zaradi tega tudi sama podlegajo logiki delovanja jezikovnih zvrsti in prav tako pri gledalcih povzročajo negativne učinke, kadar to logiko nenačrtovano kršijo.

V slovenskem jezikovnem prostoru obstajajo številne narečne skupine in podskupine, ki se med sabo ločijo do te mere, da lahko povprečno izobražen Slovenec 
narečnega govorca že po nekaj izrečenih besedah spontano vsaj približno uvrsti v ustrezno narečno skupino in s tem na ustrezno območje, kjer je tak govor avtohton (prim. npr. Toporišič 2000, Logar 1993 idr.). To pomeni, da je povprečen gledalec ali poslušalec ravno tako sposoben prepoznati dialekt, ki ga sliši na odru, in s tem dogajanje tudi ustrezno geografsko umestiti. Ne samo da to postavlja gledalce v neenakopraven položaj (glede na narečno skupino, ki ji pripadajo), ampak tudi vpliva na sprejemanje drame oz. uprizoritve kot celote. Načrtovana uporaba dialektizmov oz. doseganje določenih učinkov, ki jih dosega tudi izvirnik, lahko to dramsko konstrukcijo v ciljnem jeziku okrepi, v nasprotnem primeru pa deluje zavajajoče.

Nevarnost takšnih kršitev oz. prebojev jezikovnega podsistema pa ne grozi zgolj izvirnemu besedilu, ampak še toliko bolj prevodu, saj glavni del medkulturnega prenosa besedila poteka prav na ravni jezika in je $v$ veliki meri odvisen od spretnosti prevajalčevega manipuliranja z izraznimi možnostmi. Na eni strani izvirni jezik njihovo uresničitev zahteva, na drugi pa jo ciljni ponuja ali pa - v redkejših primerih tudi ne. Prevajalec se mora zato ves čas nastajanja prevoda dobro zavedati problema namernih in nenamernih zvrstnih neskladij. Slovenska prevajalska praksa namreč kaže, da je razlog za odmike prevoda od izvirnika velikokrat prav prevajalčeva nepozornost na določen prevajalski problem, ki v resnici sploh ni nerešljiv.

\section{Analiza rabe pogovornih in narečnih elementov v prevodu Pinterjevega Hišnika}

Ta študija analizira uporabo pogovornih in narečnih izrazov v slovenskem prevodu drame Hišnik (angl. The Caretaker) britanskega dramatika Harolda Pinterja. Prevodno besedilo ima s tega vidika kar nekaj pomanjkljivosti, med katerimi so najbolj opazne naslednje: zelo močna zaznamovanost besedila s prvinami ljubljanskega pokrajinskega pogovornega jezika ${ }^{1}$ in delno tudi gorenjskega narečja ${ }^{2}$, pogosta neutemeljenost pojavljanja pogovornih in narečnih izrazov v prevodu, nedoslednost $\mathrm{v}$ uporabi le-teh, moteča pa je tudi prevelika frekventnost njihovega pojavljanja $\mathrm{v}$ primerjavi z izvirnikom. Zaradi narave slovenskega jezika se nekaterim od teh premikov skorajda ni mogoče izogniti, $v$ mnogih primerih pa bi se s predhodno analizo izvirnika in načrtovano, torej ne naključno prevajalsko strategijo lahko našle vsaj boljše, če že ne optimalne rešitve.

Sklop opaznejših prevodnih premikov izvira iz prevajalčeve odločitve, da pogovorne izraze $\mathrm{v}$ prevodu nadomesti s pokrajinskim pogovornim jezikom ${ }^{3}$ in narečjem. Tudi izvirnik sicer ni napisan izključno v standardni različici angleškega

1 Jezikovne posebnosti ljubljanskega jezika najdemo zbrane predvsem pri Toporišiču (prim. npr. 1970, 65-6; 2000, 22), nekatere pa navaja tudi Makarova v okviru raziskave variantnosti ljubljanščine (2004, 287-8).

2 Za značilnosti gorenjskega narečja glej Logar (1993, 106-10).

3 Nekateri dialektologi za pokrajinski pogovorni jezik uporabljajo izraz nadnarečje (prim. V. Smole 1997). Tudi Toporišič (2000, 21-3) ga uporabi pri definiciji pojma pokrajinski pogovorni jezik, katerega opiše kot nadrejenega narečjem - v podobnem smislu, kot je 
jezika, vendar pa vsebuje le pogovorne in nižje pogovorne elemente, ki se po svojem konotativnem potencialu predvsem zaradi geografske nevtralnosti bistveno razlikujejo od pokrajinskih pogovornih in narečnih.

Nestandardna raba jezika $v$ izvirniku je dosežena $z$ naborom različnih jezikovnih in slogovnih elementov. Med najopaznejšimi so leksikalne izbire, torej raba izrazov ali besednih zvez, ki same po sebi spadajo v nižjepogovorni jezik, pogovorne slovnične strukture, ki v standardni različici jezika veljajo za nepravilne, razni pravopisni in pravorečni odkloni od norme, neformalni jezikovni elementi ter (pogosto »ustaljene«) jezikovne napake. Za pričujočo razpravo je pomembno poudariti dejstvo, da nižji registri, ki so uporabljeni v besedilu Hišnika, z jezikovnimi sredstvi niso vezani na nobeno angleško govorečo regijo, čeprav je iz drame razvidno, da se dogajanje odvija $v$ Londonu, dramske osebe pa $\mathrm{v}$ pogovoru omenjano tudi številne kraje iz njegove okolice. Pogovorne jezikovne elemente lahko ponazorimo z nekaj primeri:

DAVIES. You got an eye of him, did you? (Pinter 1990, 19)

DAVIES. This your room? (Pinter 1990, 20)

DAVIES. Well you've got some knick-knacks here all right, I'll say that. (Pinter 1990, 22)

DAVIES. What about them shoes I come all the way here to get I heard you was giving away? (Pinter 1990, 24)

Besedna zveza got an eye of him $\mathrm{v}$ prvem primeru je pogovorna, nepravilno pa je rabljena tudi vprašalna fraza did you?, ki bi v standardni rabi ob trdilnem stavku morala biti vprašalno-nikalna, torej didn't you? . V drugem primeru je izpuščen glagol is; pravilno bi se vprašalna poved glasila Is this your room?; tovrstne eliptičnosti standardni angleški jezik ne dopušča. Tretja replika vsebuje pogovorni izraz knick-knacks, kar pomeni ljubke (pogosto okrasne) drobne predmete, nadalje pa je slovnična struktura have got v pomenu have (sl. imeti, posedovati) ob tem, da je že sama po sebi pogovorna, rabljena tudi v okrajšani obliki you've got. V koncu replike imamo še dve mašili, all right in I'll say that, ki prav tako spadata v domeno pogovornega (predvsem govorjenega) jezika. Kot mašilo bi lahko razumeli celo prislov here, saj je iz sobesedila razvidno, da se Davisova pripomba nanaša na predmete $\mathrm{v}$ istem prostoru. Zadnji primer pa zveni okorno in zapleteno že zaradi rabe dveh zaporednih istovrstnih odvisnikov, pri čemer je drugi še sestavljen - vsi trije pa so brez uvajalne vezniške besede: I come all the way here to get (sl. ki sem jih prišel sem iskat) in I heard you was giving away (sl. za katere sem slišal, da jih oddajate). Izpuščanje vezniške besede je sicer v standardni angleščini povsem dopustno, vendar pa pri kopičenju odvisnikov poslušalec težje dešifrira meje in razmerja med

knjižni jezik nadrejen splošnemu pogovornemu jeziku. Podrobneje podaja le značilnosti ljubljanskega pokrajinskega pogovornega jezika, ostale skupine pa samo bežno omenja. Na tem mestu velja poleg povedanega opozoriti tudi, da poleg Toporišičevega koncepta razvrstitve socialnih zvrsti - na katerega se zaradi njegove sedanje razširjenosti in uveljavljenosti naslanja tudi ta razprava - obstajajo tudi drugačni predlogi te delitve socialnih zvrsti jezika, npr. predlog V. Smole (2004, 323). 
njimi, zato postaja sporočilo nejasno in daje občutek neurejenosti oz. sprotne ali naključne gradnje povedi, kar pa je zopet bolj v domeni pogovornega jezika. Poleg tega sta $\mathrm{v}$ tem primeru močno opazni tudi nedovoljena akuzativna raba osebnega zaimka them na mestu, kjer mora stati določni člen the, in nepravilni pomožnik was namesto slovnično pravilnega were.

V izvirnem Hišniku ${ }^{4}$ je jezik pri odkrivanju osebnostnih lastnosti nastopajočih dramskih oseb zaradi mestoma pogovornega značaja močno pomenljiv. Raba pogovornih fraz in jezikovne napake skozi vso dramo kažejo na nižjo izobrazbeno stopnjo ter socialni in družbeni položaj oseb, na posameznih mestih pa tudi na njihovo psihično stanje, odnos do okolja ali trenutno namero. Uporaba pokrajinskega pogovornega jezika in narečja $\mathrm{v}$ slovenskem prevodu nekatere izmed teh konotacij sicer ohranja, vendar jih s svojo temeljno značilnostjo, to je vezanostjo na specifičen geografsko omejen prostor, hkrati tudi močno zasenči.

Prevajalec se je pri rabi neknjižnih elementov v slovenskem prevodu Hišnika omejil na značilnosti gorenjske narečne skupine, ljubljanskega pokrajinskega pogovornega jezika in splošno- ali knjižnopogovornega jezika. Njegovo odločitev lahko povežemo z dejstvom, da je prevod naročilo Prešernovo gledališče Kranj in da je bila postavitev primarno namenjena uprizarjanju na tamkajšnjem odru. Enako ugotavlja tudi komentator Gorenjskega glasa, torej da prevod »nakazuje opazne pogovorne prvine zlasti v jeziku brezdomca Daviesa, kar je v interpretaciji Poldeta Bibiča dobilo opazne gorenjsko obarvane intonacije, ustrezno kraju nastanka predstave « (Vurnik 1990, 7). Negativne posledice take izbire jezikovnih sredstev so opazne že pri tej postavitvi, večji problem pa predstavlja njen vpliv na vsa nadaljnja ugledališčenja, ki bi utegnila nastati na osnovi iste prevodne predloge.

Na jezikovni ravni je kranjski Hišnik izgubil precej nevtralnosti, kar občutijo predvsem gledalci iz negorenjskega okolja, nakopal pa si je tudi nekatere pomenske odtenke, ki jih izvirnik ne predvideva. Med slednje spada očitno sugeriranje Daviesovega »gorenjskega« oz. v principu kateregakoli definiranega porekla, ki močno ruši Pinterjev koncept skrivnostnosti, katerega namen je onemogočiti gledalcu vsakršen poskus razkrivanja identitete oseb ali njihovega nejasnega ozadja.

$Z$ vnašanjem elementov ljubljanščine in gorenjščine na tako zgodnji stopnji, torej že na nivoju prevoda, je prevajalec precej zmanjšal verjetnost, da bodo po isti prevodni predlogi posegle tudi druge slovenske gledališke skupine. Besedilo, ki je dorečeno do te mere, onemogoča kreativnost in morebitno prilagajanje lastnim govornim ter jezikovnim posebnostim. $Z$ vidika ugledališčenja je namreč vsako (prevodno) dramsko besedilo šele polizdelek, ki v principu nudi široke interpretativne

${ }^{4}$ Hišnik je tridejanka z razmeroma preprosto fabulo, a hkrati izjemno kompleksno dramsko strukturo. Dogajanje je zaprto v sobo na podstrešju stare londonske predmestne hiše $\mathrm{v}$ lasti dveh bratov, Micka in Astona. Osrednji lik je potepuh Davies, ki ga Aston pripelje s seboj domov in mu ponudi začasno streho nad glavo, pozneje pa celo službo hišnika. Kasneje izvemo, da ga je v bifeju, kjer je starec delal kot čistilec, rešil iz prepira z njegovim delodajalcem. Davies je sprva veselo presenečen, kmalu pa postane nehvaležen in pohlepen. $Z$ dokaj nespretnimi manipulacijami poskuša naščuvati brata drugega proti drugemu, a mu nazadnje spodleti. Kmalu spozna, da sta mu oba brata obrnila hrbet in da je s svojim spletkarjenjem zapravil veliko priložnost. 
možnosti celi vrsti poustvarjalcev. Prevajalec, ki je zaradi medkulturnega prenosa besedila na začetku te verige, pa bi si, kot poudarja tudi Moravec v Temeljih slovenske teatrologije (1980), moral prizadevati za čim večjo nevtralnost in interpretativno odprtost prevoda. Modrov prevod je dramo in njeno uprizoritev morda res nekoliko približal občinstvu osrednjeslovenskega prostora, hkrati pa ju je na to območje tudi omejil. Za zvestobo prevoda izvirniku se zavzema tudi D. Hribar (1999), v zvezi s tem pa opozarja še na nevarnost raznih nestrokovnih predelav, s katerimi bi se zaradi prirejanja takšnega prevoda drugačnim potrebam njegovo bistvo utegnilo še bolj oddaljiti od avtorjeve namere:

Ne glede na posebnosti slovenske gledališke prakse /.../ bi moral vsak dramski prevod biti narejen na osnovi prevajalskih norm in strategij, ki omogočajo karseda širok vpogled v izvirnik, v ciljnem jeziku in kulturi pa dramaturško razčlembo, ki posebnosti besedila izvirnika zazna tudi v prevodu (Hribar 1999, 197).

Uporabo pogovornega ali narečnega izraza $\mathrm{v}$ prevodu je večinoma mogoče utemeljiti s pojavom pogovornega ali narečnega izraza na ustreznem mestu v izvirniku. Redkeje pa se zgodi, da se prevajalec odloči za uporabo takega izraza, čeprav je njegova predloga v izvirniku nevtralna. Vzrok za tako odločitev je navadno t. i. princip kompenzacije, to je nadomeščanje slogovno zaznamovanih slovničnih ali skladenjskih struktur, ki se sicer ne dajo neposredno prenesti v ciljni jezik, s pogovornimi ali narečnimi izrazi. To seveda deluje samo v določenih primerih, ko je izpolnjena še vrsta drugih pogojev, ne glede na svojevrstnost posameznih primerov pa mora biti vsaka odločitev prevajalca nujno $\mathrm{v}$ skladu s prevajalsko strategijo in normami, ki veljajo za celoten prevod. V slovenskem prevodu Hišnika je neutemeljeno pojavljanje ljubljanskih pokrajinskih pogovornih izrazov in gorenjskih narečnih besed sorazmerno pogosto. To nakazuje možnost, da je prevajalec želel še močneje okarakterizirati Daviesa ter izpostaviti razliko med njim in Astonom tudi z izborom jezikovnih sredstev, vendar mu za takšen poseg izvirnik ne daje nobene osnove.

Med neknjižnimi elementi se najpogosteje pojavljajo tisti na leksikalni ravni: bodisi besede, ki so lastne ljubljanščini ali gorenjščini, npr. špital, porajtal, plonk, tle (v pomenu: bolnišnica, se zavedel, brez denarja, tukaj), zelo opazno pa je tudi prirejanje besed, ki postanejo zaznamovane zaradi značilnega popačenja enega ali več glasov oz. zaradi t. i. moderne vokalne redukcije ali samoglasniškega upada (prim. Logar 1993, Toporišič 2000). Med slednjimi so pogoste besede, ki vsebujejo črkovni sklop $\boldsymbol{a} \boldsymbol{j}$, v Daviesovih replikah pa je le-ta večinoma reduciran v $\boldsymbol{e j}$. Toporišič (2000) ta glasoslovni pojav uvršča med značilnosti neknjižnega pogovornega jezika, ki rade vdirajo v knjižnopogovorni. Tako besede zdaj, saj, majhen, nekaj, velelniki druge osebe v ednini kot so daj, poslušaj itd., v prevodu skoraj vedno postanejo zdej, sej, mejhen, nekej, dej, poslušej, npr.:

DAVIES. Nej si poiščem kej druzga? (Pinter 1990, 53)

DAVIES. Find somewhere else? (Pinter 1977, 77)

O premalo jasno izdelani prevajalski strategiji priča tudi prevajalčeva nedoslednost $\mathrm{v}$ rabi narečnih in pogovornih elementov, kar je zopet najbolj opazno na leksikalni ravni. Pogosto se dogaja, da se beseda, ki se v replikah iste osebe večinoma pojavlja v ljubljanski pogovorni ali v narečni obliki, brez oprijemljivega razloga pojavi v knjižni obliki: 
DAVIES. Kaj pa češ od mene, naj jenjam dihat? (Pinter 1990, 52)

DAVIES. What do you want me to do, stop breathing? (Pinter 1977, 75)

Če primerjamo angleška izvirnika v gornjih dveh primerih, vidimo, da ne dajeta razloga za tolikšno nihanje jezikovne rabe $\mathrm{v}$ prevodu. $\mathrm{V}$ izvirnem besedilu so replike iste osebe seveda notranje slogovno usklajene, prevod pa je pogosto nedosleden. Še posebej je ta nedoslednost očitna takrat, kadar se znotraj iste replike ali iste povedi hkrati pojavijo besede iz različnih jezikovnih registrov, torej pogovorne in knjižne:

DAVIES. Hja, veste kaj ... majčkeno počakejte ... jaz ... jaz do zdej še nikoli nisem bil za hišnika, veste ... (Pinter 1990, 38)

DAVIES. Well now ... wait a minute ... I ... I ain't never done no caretaking before, you know ... (Pinter 1977, 59)

Zelo pogosto se zapuščanje knjižne domene dogaja tudi pri izpadanju glasu $\boldsymbol{i}$ sredi besede, kadar je nenaglašena glagolska pripona ali pa kadar se pojavi v priponskem obrazilu - t. i. popolna vokalna redukcija, vendar tudi to ni popolnoma dosledno. Med okrnjenimi pogovornimi oblikami žuljo, napravta, potlačli, skodelco, žagco se tako pojavijo tudi oblike, pri katerih $\boldsymbol{i}$ ne izpade: rogovilijo, mislite, napraviš, pritisnit. Izgubljajo se tudi drugi samoglasniški glasovi, npr. v besedah morte, prčakvat, dobrga, vsega mogočga, prav tako pa lahko naletimo tudi na morajo, mojega, ne morem.

Kot pričajo nekateri že navedeni primeri, predvsem pa prevod v celoti, iz slovenskega besedila ni popolnoma razvidno, kje je prevajalec postavil mejo med knjižnim in neknjižnim jezikom oz. na osnovi česa se je v posameznih primerih odločal, katere izraze bo postavil v neknjižno obliko in katerih ne. Posledica tega je nastanek mešanice besed, ki pripadajo različnim socialnim zvrstem jezika, kar pa ne zveni naravno. To je gotovo v nasprotju s Pinterjevo dramsko taktiko posnemanja naravnega govora, česar se morajo poznavalci njegovega sloga med gledališčniki dobro zavedati. Takšna prevodna predloga lahko torej zahteva dodatne dramaturške posege $\mathrm{v}$ besedilo še pred uprizoritvijo, $\mathrm{v}$ vsakem primeru pa postavlja $\mathrm{v}$ neugoden položaj tudi vse druge soustvarjalce predstave (režiserja, lektorja ${ }^{5}$, igralce ...), saj besedilna predloga bistveno vpliva tudi na njihov končni izdelek - pri njeni uporabi in (pre)oblikovanju pa seveda nimajo neomejenih pooblastil.

Oglejmo si odlomek iz Hišnika, ki kaže na nedodelanost strategije pri rabi knjižnega oz. neknjižnega jezika. V njem so neknjižni izrazi v celoti natisnjeni krepko, medtem ko je v tistih knjižnih, ki bi z isto utemeljitvijo lahko bili v neknjižni obliki, vendar se prevajalec za to ni odločil, krepko natisnjeno samo mesto, ki ločuje med eno in drugo obliko:

DAVIES. /.../Zmerej mi je porinil kakšen košček mila, vselej, kadar sem prišel tje. Zlo dobrga mila. Tam morajo imet najboljše milo. Nikoli nisem bil brez koščka mila, kadar sem takole mimogrede zavil v tisti konc (Pinter 1990, 7).

5 O posegih v besedilo, ki so v pristojnosti lektorja, prim. Podbevšek (1998, 83-4); posebej je izpostavljena tudi situacija, ko je dramsko besedilo prevod. 
Rabo kratkega nedoločnika imet dopušča že knjižnopogovorni jezik; izraza zmerej in tje Toporišičeva klasifikacija označi za neknjižna, vendar s pogovornimi značilnostmi, ki rade vdirajo v knjižnopogovorni jezik; zlo, dobrga in konc pa spadajo v domeno ljubljanskega pokrajinskega pogovornega jezika (Toporišič 2000, 16-22). Postavlja se vprašanje, zakaj v izrazih nikoli in tisti ni opuščen končni $\boldsymbol{i}$, za kar je utemeljitev mogoče najti na istem mestu kot za zmerej in tje, izraza morajo in takole pa bi z izpustom glasu $\boldsymbol{a}$ prestopila v ljubljanščino in se tako zvrstno uskladila z zlo, dobrga in konc. Ti štirje bi zaradi doslednosti gotovo zaslužili neknjižno obliko, razmisliti pa bi veljalo še o porinil, prišel in mimogrede oz. o njihovih neknjižnih oblikah porinu, pršs in mimgrede.

Raba neknjižnih izrazov tudi v takšnih in podobnih primerih bi jezik posameznih oseb v prevodu sicer poenotila, v najboljšem primeru bi tudi npr. Daviesov govor, kljub pokrajinskemu pogovornemu značaju, dosegel celo optimalno notranjo ustaljenost, kar bi zbujalo občutek naravnega govora. Vendar pa to še zdaleč ne bi pomenilo jamstva, da je razmerje med rabo pokrajinsko zaznamovanega in knjižnega jezika ustrezno in skladno z izvirnikom.

Primerjava frekventnosti pojavljanja neknjižnih izrazov med angleškim in slovenskim Hišnikom pokaže, da je v prevodu že sedaj mnogo več pogovornih in narečnih besed, kar pomeni, da bi se pri takšnem zvrstnem usklajevanju jezika na račun dodajanja neknjižnih izrazov razmerje še bolj porušilo. Takšna rešitev je torej že zaradi tega manj primerna, poleg večje številčnosti pa so neknjižni izrazi v prevodu tudi intenzivnejši, torej so njihovi odkloni od norme večji kot v izvirniku. Primerjajmo zgoraj navedeno Daviesovo pripoved o milu z ustreznim odlomkom iz izvirnika:

DAVIES. /.../ Always slipped me a bit of soap, any time I went in there. Very good soap. They have to have the best soap. I was never without a piece of soap, whenever I happened to be knocking about the Shepherd's Bush area (Pinter 1977, 22).

Teritorialno vezanih izrazov $\mathrm{v}$ takšnem smislu, kot jih srečamo v prevodu, $\mathrm{v}$ izvirniku pravzaprav ni, pa tudi izrazito pogovornih prvin je neprimerno manj. Pogovorno obliko imata $\mathrm{v}$ navedenem odlomku le krajevni prislov in there zaradi predloga in ter izraz knocking about v pomenu potepati se okrog ali hoditi okrog brez določenega cilja. Razen tega lahko za pogovorno prvino štejemo tudi eliptičnost $\mathrm{v}$ prvih dveh povedih; $\mathrm{v}$ prvi je izpuščen osebek he, $\mathrm{v}$ drugi pa poleg osebka it tudi glagol was.

\section{Diskusija}

Prekomerno nagibanje jezika $v$ druge socialne zvrsti v procesu prevajanja lahko močno vpliva celo na globalno strukturo drame. Dialekt in pokrajinski pogovorni jezik zaradi opisanih implikacij torej nista primerna za prevajanje neknjižnih jezikovnih prvin v drami na splošno, seveda velja to tudi za analizirano dramo. Po drugi strani pa bi bilo tudi prevajanje teh elementov v zborni jezik neustrezno, saj 
mora biti razlika med višjim in nižjim nivojem jezika, ki je prisotna v izvirnem Hišniku, nujno zaznavna tudi v prevodu. Strinjanje s tem so izrazili številni jezikoslovci in prevajalci, ki se ukvarjajo s problemom prevajanja nestandardnih plasti jezika (npr. Sauer (prim. Gogala 2001), Findlay 2000 itd.), na teoretski ravni pa tudi Hatim in Mason:

Rendering source language text dialect by target language standard has the disadvantage of losing the special effect intended in the source language text, while rendering dialect by dialect runs the risk of creating unintended effects (Hatim in Mason 1990, 41).

V načelu bi bil za tak prevod primeren slovenski pogovorni jezik, a težava, na katero naleti prevajalec pri poskusu njegove uporabe v primerih, s kakršnim se srečamo v Hišniku, je njegova že omenjena regionalna zaznamovanost. Slovenski jezik v resnici nima neke splošne vseslovenske pogovorne ali nižjepogovorne variante, ki bi označevala povprečnega oz. »splošnega« neizobraženca ali potepuha in ki hkrati ne bi bila vezana na govor določene regije. Kakor hitro se jezik v rabi odmakne z zborne ravni, se znajde na ravni pokrajinskega pogovornega jezika ali celo narečja. Koncept splošnega pogovornega jezika, ki ga znotraj svoje klasifikacije zvrstnosti slovenskega jezika navaja Toporišič (2000, 13-24), je sicer teoretsko dobro zamišljen, vendar v praksi ni tako živ kot v teoriji, kar pa dramskemu prevajalcu s konkretnim prevajalskim problemom ni v realno pomoč. Nekoliko protislovna je celo sama definicija, ki po eni strani poudarja univerzalnost pogovornega jezika tako z imenom (»splošni pogovorni« v nasprotju s »pokrajinskim pogovornim«), kakor tudi z opisom - po drugi strani pa je iz nje mogoče razbrati privilegiranost osrednjeslovenskega prostora:

Splošno- ali knjižnopogovorni jezik je nekaka manj popolna uresničitev stroge zborne norme, ker se bolj kakor zborni opira na navadno vsakdanjo občevalno govorico nenarečno govorečih ljudi na celotnem slovenskem ozemlju, posebno pa v njegovem osredju, tj. v Ljubljani in njenem bolj ali manj urbaniziranem širšem okolju (Toporišič 2000, 16).

Isto pomanjkljivost ugotavlja tudi Mlakarjeva $\mathrm{v}$ razpravi na simpoziju o slovenskem jeziku na odru, ki je spremljal Borštnikovo srečanje 1982:

Splošna pogovorna varianta je nekoliko znižana, zlajšana oblika zbornega jezika. To kar je zdaj v Načrtu [Načrtu pravil za novi slovenski pravopis 1981, op. T. O.] opisano kot splošni pogovorni jezik, po mojem preveč spominja na ljubljansko pogovorno varianto (Tomše 1983, 118).

Prve tri izdaje Slovenske slovnice (Toporišič 1976, 1984, 1991) so poleg zgoraj navedene definicije splošnemu pogovornemu jeziku pripisovale še številne značilnosti, ki v smislu teritorialne nevtralnosti - vsaj intuitivno - tja nikakor ne sodijo. Zaradi nazornosti jih je smiselno ponazoriti kar s primeri iz Hišnika: smo delal, smo prosil, smo nesl; snoč, ponoč; za tem visokim goram; men, teb; ribca, rokca; vzdignte; tolko, kolko, prov, delov; zdej itd. (Pinter 1990, 2-62). Večina navedenih primerov ponazarja izpadanje $i$-ja, kar resnično daje splošnemu pogovornemu jeziku značaj ljubljanskega govora. To za govorce ostalih slovenskih regij ni in ne more biti sprejemljivo, kar potrjuje tudi diskusija Brede Pogorelec na mariborskem simpoziju o slovenskem odrskem jeziku, v okviru Borštnikovega srečanja 1982: 
Tržaški kolegi so se upirali temu, da bi oni morali posamezne besede reducirati tako kot $\mathrm{v}$ Ljubljani. Ker je naš pogovorni jezik izjemno raznoroden, ima pač variante, ki jih je treba dopustiti. To je popolnoma jasno in prav nič slabo (Tomše 1983, 114).

Zadnja, četrta izdaja slovnice (Toporišič 2000) je številne v gornjem odstavku navedene primere, ki bodisi podlegajo redukciji $i$-ja ali pa kateri drugi pokrajinski značilnosti, izločila iz knjižnega jezika ter jih uvrstila pravzaprav nekam na rob dosedanje klasifikacije, in sicer med »značilnosti neknjižnega pogovornega jezika, ki rade vdirajo v knjižnopogovornega«. Vendar pa so v smislu pokrajinskega prizvoka tudi med besednimi (predvsem glagolskimi) oblikami, ki po najnovejši Toporišičevi delitvi ostajajo $\mathrm{v}$ domeni splošnega pogovornega jezika, nekatere $\mathrm{z}$ vidika intuitivne percepcije še vedno oporečne; na primer oblike: smo delal, smo prosil; reku, vidu, vedu itd. (Pinter 1990, 2-62). Tudi teh bi se moral prevajalec v korist nevtralnosti in odprtosti prevoda izogibati. Ključnega pomena pri tem je pridevnik »intuitiven«, ki gotovo spada skoraj izključno v domeno subjektivnega doživljanja pojavov okolja in sam po sebi ne sodi v znanstveno razpravo o zvrstnosti jezika. Prisotnost intuicije in njena vloga postaneta jasni šele spričo dejstva, da je jezik drame in gledališča živ ter da je sprožanje subjektivne percepcije eden njegovih osnovnih namenov. Pri tem ima govor kot medij osrednjo vlogo, učinkuje pa prav tako subjektivno, saj s svojo zunanjo podobo deluje tudi na gledalčeva čustva ${ }^{6}$ Za slednjega je torej dejstvo, da je določena beseda oz. besedna prvina $v$ nekem veljavnem jezikovnem priročniku označena kot splošna pogovorna, povsem nerelevantno. Povprečen gledalec s tem najverjetneje niti ni seznanjen, pa tudi če je, se ob gledanju dramske predstave zanaša na občutke in ne na racionalno pridobljeno teoretsko znanje jezika.

\section{Nekaj ugotovitev in smernic}

Ugotovitve v prejšnjem razdelku sicer dobro opredelijo enega ključnih problemov prevajanja pogovornih in narečnih elementov v slovenski prevajalski pra$\mathrm{ksi}$, vendar podajajo le delne in hkrati precej načelne napotke, kako ravnati v takih primerih. Sodobna translatologija nima celostnega odgovora na to vprašanje in ga zaradi izraznih možnosti in specifike posameznih jezikov v splošnem tudi ne more podati, lahko pa ponudi smernice in drobne praktične nasvete, seveda brez zagotovila, da bodo delovali v vsaki prevajalski zagati.

Med takimi možnostmi je tudi prevajalska strategija, ki jo nakazuje že prejšnji razdelek, to je prevajanje angleških pogovornih elementov z njihovimi geografsko nevtralnimi slovenskimi pogovornimi ustreznicami. Ta rešitev zveni na prvi pogled preprosto, toda precej težje je vztrajati pri njenem doslednem izvajanju ter pri iskanju ustreznih rešitev v posameznih primerih. $Z$ izločitvijo prej omenjenih (in podobnih) skupin teritorialno zaznamovanih besed ter njihovih pokrajinskih oblik

${ }_{6}$ Pri subjektivni in čustveni percepciji igrajo poleg samega govora pomembno vlogo tudi njegove neverbalne komponente, kar je na odru zagotovo prisotno. V zvezi s tem prim. tudi Poyatos (1997, 23-35 in 1983) ter Hribar (2001). 
in struktur postane splošni pogovorni jezik za prevajalca uporabnejši, saj je »pridobil na splošnosti«. Prevajalec se lahko - seveda deloma zopet po svoji intuitivni presoji - približa nekemu optimalnemu fondu pogovornih jezikovnih sredstev, ki so kar najbolj »splošna« in s tem uporabna v prevajalski zagati, kakršna je nastala pri prevajanju Daviesovega govora v Hišniku. Opisani postopek ni zgolj rutinsko ali mehanično izločanje besed na splošno, niti ne deluje na principu intuicije v tem smislu, da bi se prevajalec brez predhodno izoblikovanega namena odločal pri vsakem izrazu posebej, ali ga bo obdržal ali opustil. Osnovno vodilo pri izvajanju postopka mora biti jasna in vnaprej izoblikovana globalna prevajalska strategija, ki jo prevajalec izdela skladno s pomenskim potencialom izvirnika ter $\mathrm{z}$ vlogo pogovornega jezika $\mathrm{v}$ njem. $\mathrm{Z}$ njo prevajalec utemeljuje svoje odločitve $\mathrm{v}$ posameznih konkretnih primerih.

Fond pogovornih besed in besednih oblik, ki nastane na ta način, je torej »prečiščen«, vendar se je istočasno treba zavedati tudi negativne posledice takega postopka, to je skrčenja obsega pogovornega jezika in s tem prevajalčevega manevrskega prostora. Iz dobljenega jezikovnega korpusa so namreč izginile številne pokrajinsko obarvane besedne oblike in strukture, pri katerih je nižjepogovorni prizvok, s katerim bi lahko pripomogle $\mathrm{k}$ ustvarjanju pogovornega značaja besedila, skrit prav v njihovi pokrajinski noti. Skrčenje besedne domene je v načelu res pomanjkljivost, drži pa tudi, da zoženje nabora leksikalnih izbir, s katerim se sooča prevajalec, pri prevajanju pogovornih replik navadno ustreza omejenemu obsegu govorčevega besednega zaklada.

Okrnjene izrazne možnosti lahko predstavljajo problem pri prevajanju besedil, $\mathrm{v}$ katerih je gostota pogovornih izrazov razmeroma visoka, torej bistveno višja kot v izvirnem Hišniku. V takšnih primerih je v praksi dokaj uporabna možnost metoda kompenzacije, pri kateri se nastali primanjkljaj nadomesti z drugimi pokrajinsko nevtralnimi jezikovnimi sredstvi, ki imajo podoben ali skoraj enak učinek na sprejemnika kot izvirni jezikovni element. Zelo učinkovito je lahko prevajalčevo namerno vnašanje drobnih slovničnih in pravorečnih napak v pogovorne replike. Kljub temu da je v knjižnem jeziku to nedopustno, je uporaba te tehnike v pogovornih prevodnih besedilih pogosto utemeljena in umestna. Napake se namreč pojavljajo tudi v naravnem govoru, predvsem v njegovih nižjepogovornih različicah, in sicer še posebej, če je govorec neizobražen in ne pozna pravil knjižne norme. Poleg tega je takšen korak velikokrat utemeljen tudi s samim izvirnim besedilom, saj so njegovi pogovorni deli, ki predstavljajo znaten del Pinterjeve strategije posnemanja naravnega govora, pogosto hkrati tudi slovnično nepravilni. Te napake so zaradi narave vsakega posameznega jezika mnogokrat medjezikovno in medkulturno neprenosljive. Zato jih je treba v ciljnem jeziku nadomestiti z ustrezno sorodno jezikovno napako, ki ima približno enako intenzivnost, seveda pa tudi čim bolj podoben potencialni učinek. Med napake, lastne slovenskemu pogovornemu jeziku, spadajo npr. polvikanje ali pogovorno vikanje (prim. Skaza 2000, 41), uporaba svojilnih zaimkov na mestih, kjer bi morali stati povratno svojilni, postavljanje zanikanih samostalnikov v tožilnik namesto v rodilnik ipd. Prevajalec lahko pri iskanju prevodnih rešitev $\mathrm{v}$ posameznih primerih uporabi tudi številne nepravilne 
fraze ali skladenjske konstrukcije, ki jih najde npr. v Sršenovem (1998) ali katerem drugem podobnem jezikovnem priročniku.

\section{Sklep}

Vsi do sedaj navedeni in opisani mehanizmi so za ustvarjanje vtisa nižje pogovornosti karseda pripravni, vendar mora biti prevajalec ves čas pozoren, da z njihovo uporabo ne pretirava in ne krši zvestobe izvirniku. Seveda se je treba zavedati, da idealen prevod ni mogoč. $V$ ciljnem jeziku je pogosto težko najti besedo ali besedno zvezo, ki bi ohranila vse pomenske razsežnosti izvirnega besedila, zato se mora prevajalec $\mathrm{v}$ takem primeru kateri od njih odreči. Je pa $\mathrm{v}$ dani situaciji vedno mogoče poiskati optimalno rešitev, ki upošteva čim širše možnosti za razumevanje ali poustvarjanje besedila, hkrati pa se poskuša izogniti najopaznejšim oz. za gledalca najbolj motečim premikom. Uporaba pogovornih in narečnih jezikovnih elementov lahko prevod povzdigne na optimalni nivo kakovosti in ga s tem naredi uporabnega samo, če je premišljena in dosledna. Zato morajo biti prevodne rešitve, ki se pojavijo v končni različici prevoda, $v$ skladu z globalno prevajalsko strategijo, seveda pa tudi z ostalimi segmenti jezikovne in dramske strukture besedila.

\section{Viri in literatura}

Findlay, Bill, 2000, Translating Standard into Dialect: Missing the target?, Moving Target, ured. Carole-Anne Upton, 35-46, Manchester, Northampton MA, St. Jerome Publishing.

Gogala, Viljem, 2001, Walter Sauer, prevajalec v pfalščino, Delo, KL, 14. 11., 11.

Hatim, Basil in Ian Mason, 1990, Discourse and the Translator, London, New York, Longman.

Hribar, Darja Darinka, 2001, Nebesedna komunikacija v prevodu, Vestnik 35, št. 1-2, 385-398.

Hribar, Darja Darinka, 1999, Sestavine sloga Harolda Pinterja v slovenskih prevodih: vpliv slogovnih posebnosti na sprejemanje na Slovenskem, Neobjavljena doktorska disertacija, Univerza v Ljubljani.

Logar, Tine, 1993, Slovenska narečja, Besedila, Ljubljana, Mladinska knjiga.

Makarova, Irina, 2004, Mehanizem jezikovnega prilagajanja in variantnost sodobne ljubljanščine, Obdobja 22. Aktualizacija jezikovne resničnosti na slovenskem: členitev jezikovne resničnosti, ured. Erika Kržišnik, 287-95, Ljubljana, Filozofska fakulteta.

Moravec, Dušan, 1980, Temelji slovenske teatrologije, Ljubljana, Cankarjeva založba.

Pinter, Harold, 1990, Hišnik (delovni prev. Janko Moder, v tipkopisu), Prešernovo gledališče Kranj.

Pinter, Harold, 1977, The Caretaker, Complete Works Two, 14-87, New York, Grove. 
Podbevšek, Katja, 1998, Lektoriranje govorjenega (gledališkega) besedila, Jezik in slovstvo XLIII, št. 3, 79-88.

Poyatos, Fernando, 1997, Aspects, problems and literary challenges of nonverbal communication in literary translation, Nonverbal Communication and Translation, ured. Fernando Poyatos, 17-48, Amsterdam in Philadelphia, John Benjamins.

Poyatos, Fernando, 1983, New Perspectives in Nonverbal Communication: Studies in Cultural Anthropology, Social Psychology, Linguistics, Literature, and Semiotics, Oxford, Pergamon Press.

Smole, Vera, 2004, Nekaj resnic in zmot o narečjih v Sloveniji danes, Obdobja 22. Aktualizacija jezikovne resničnosti na slovenskem: členitev jezikovne resničnosti, ured. Erika Kržišnik, 321-30, Ljubljana, Filozofska fakulteta.

Smole, Vera, 1997, Slovenska narečja in zanimivejši pojavi v razvoju kratkega vokalizma, Zbornik predavanj/XXXIII. seminar slovenskega jezika, literature in kulture, ured. A. Derganc, 281-8, Ljubljana, Filozofska fakulteta.

Skaza, Jože, 2000, EPIS: Pravopisni priročnik, Dobrna, Eknjiga.

Sršen, Janez, 1998, Jezik naš vsakdanji, Ljubljana, Gospodarski vestnik.

Tomše, Dušan, ured. 1983, Jezik na odru, jezikv filmu, Ljubljana, Mestno gledališče ljubljansko.

Toporišič, Jože, 2000 (tudi izdaje 1991, 1984, 1976), Slovenska slovnica, Maribor, Založba Obzorja.

Toporišič, Jože, 1970, Slovenski pogovorni jezik, Slavistična revija 18, št. 1-2, $55-70$.

Vurnik, France, 1990, Malo oddaljena prispodoba, Gorenjski glas, 2. 10., 7.

\section{Colloquial and Dialect Expressions in Plays in Slovenian Translation: Dealing with Translation Dilemmas}

Summary

Translating texts containing non-standard linguistic elements is a predicament not only for applied translation, but also translation theory. Such elements often do not exist in the target language or have different lexical connotations. This article summarizes the findings of an analysis of a Slovenian translation of Harold Pinter's play The Caretaker (Sln. Hišnik). The author defines and investigates the critical places in the text where the translator encountered difficulty in translating colloquial expressions, and also points out shortcomings in the translation that could have been avoided by using a well-thought-out and precise translation strategy.

\section{Tomaž Onič}

Filozofska fakulteta Univerze v Mariboru

Koroška cesta 160, 2000 Maribor tomaz.onic@uni-mb.si 